\title{
Cs/K Atom Ratios of Marine Organisms of Different Trophic Levels in Japanese Coastal Waters
}

\author{
Yutaka Tateda \\ Abiko Laboratory, Central Research Institute of Electric Power Industry, \\ Abiko, Chiba 270-11, Japan
}

(Received February 22, 1994)

$\mathrm{Cs} / \mathrm{K}$ atom ratios were examined in Japanese coastal waters and biota. The $\mathrm{Cs} / \mathrm{K}$ atom ratios in coastal waters, chlorophyta ( 3 species), rhodophyta (10 species), phaeophyta (4 species), invertebrates ( 7 species), teleosts ( 15 species) were $2.1,2.1,1.9,4.6,3.5,12\left(\times 10^{-7}\right)$, respectively. The $\mathrm{Cs} / \mathrm{K}$ atom ratios were especially large in teleosts examined.

$\mathrm{Cs} / \mathrm{K}$ atom ratios in organisms increased with the elevation of the trophic levels of the organisms. An "increase ratio" of $\mathrm{Cs} / \mathrm{K}$ ratio was approximately 1.62 per one step elevation of trophic level.

The highest $\mathrm{Cs} / \mathrm{K}$ atom ratios observed in teleosts suggested both the discrimination of $\mathrm{Cs}$ from $\mathrm{K}$ in teleosts and the discrimination of $\mathrm{Cs}$ from $\mathrm{K}$ in transferring these elements along food chains.

Key words: cesium, potassium, concentration factor, atom ratio, food chain, radionuclide, Cs-137, neutron activation analysis

$\mathrm{Cs} / \mathrm{K}$ ratios were investigated in marine organisms. Original studies of $\mathrm{Cs} / \mathrm{K}$ ratios in crabs, ${ }^{1)}$ lobster and prawn. ${ }^{2)}$ were described, showing relatively higher $\mathrm{Cs} / \mathrm{K} \mathrm{ra}$ tios in tissues than in blood of these invertebrates. Further study of brackish water invertebrates suggested that the relative increase of $\mathrm{Cs}$ concentration to $\mathrm{K}$ in tissues was possibly caused by active osmotic and ionic regulation. ${ }^{3,4)}$ The physiological reason of this increases of $\mathrm{Cs} / \mathrm{K}$ ratio in tissue was attributed to the differences in the crystal radii of these ions, and the preferential binding of $\mathrm{K}$ relative to $\mathrm{Cs}$ in cells.")

While, some studies of food chains reported an increase in $\mathrm{Cs} / \mathrm{K}$ ratios in organisms of higher food trophic ranking. $\mathrm{Cs} / \mathrm{K}$ ratios in the Southern California marine biota, ${ }^{\text {) }}$ off the California Bight, and the South pacific ${ }^{6}$ suggested that $\mathrm{Cs} / \mathrm{K}$ ratios increased with elevation of trophic level, showing a factor of $1.5-2.2$ in the $\mathrm{Cs} / \mathrm{K}$ ratio per one trophic level up. The conclusion of the studies was that $\mathrm{Cs}$ was discriminated from $\mathrm{K}$ and accumulated during alkali element transport in the food chains.

In this report, the $\mathrm{Cs}_{\mathrm{s}} / \mathrm{K}$ atom ratios were measured in marine organisms of different taxa and trophic levels, aiming to clarify a magnitude of $\mathrm{Cs}$ discrimination from $\mathrm{K}$ in marine organisms, and alkali element transfer through marine food chains. To evaluate the magnitude of Cs discrimination from $\mathrm{K}, \mathrm{Cs} / \mathrm{K}$ atom ratios were used instead of $\mathrm{Cs} /$ $\mathrm{K}$ concentration ratios, which had been used in past studies. ${ }^{1-3,5,6)}$ As discrimination was assumed to have occurred due to the difference of crystal radii of these ions, ${ }^{2)}$ we should compare the increases in the numbers of each ion in various marine organism tissues by calculating atom ratios, and not by concentration ratios.

\section{Materials and Methods}

From 1984 to 1990 , biological samples and seawater were collected from the coastal areas of Japan (Oshoro
Bay, Hachinohe, Rokkasho, Sanriku, Sakata, Sado, Katsuura, Tsuyazaki), as shown in Fig. 1. Twelve samples of seawater, 57 samples of algae, including 17 different species, 12 samples of invertebrates, including 7 different species, 22 samples of fish, including 15 different species, were collected by a SCUBA diver, underwater traps, set nets and hooks. Sample sites were carefully chosen to eliminate areas affected by extreme river run-off, as freshwater inflow alters the element composition of seawater and biological conditions.

The stomach contents of organisms were sorted by taxon to assign the organisms to the appropriate trophic level. Biological samples were rinsed with clean seawater to remove attached organisms and substances. The whole-body of algae, except rhizoid, was cleaned with a paper towel to

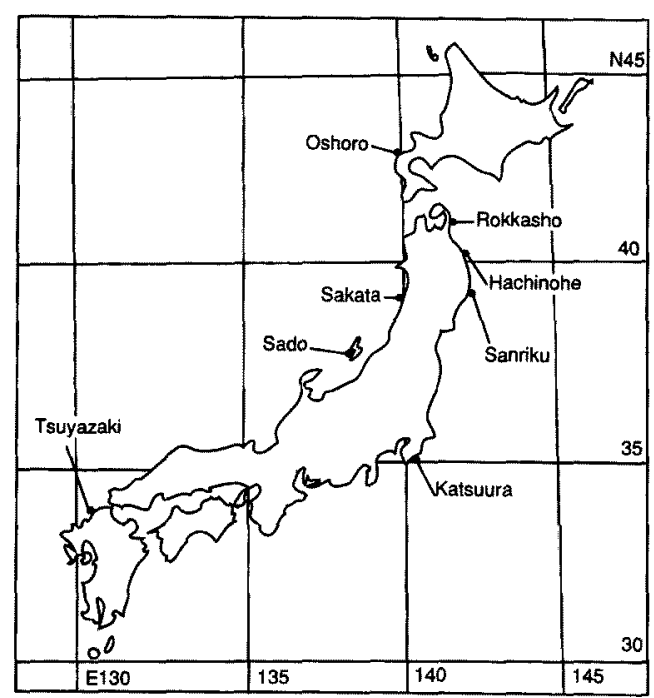

Fig. 1. Location of sampling sites. 
remove moisture from its surface, then the wet weight was measured. Samples of algae, fish flesh, muscles of sea cucumber and sea squirt, muscles and mantles of mollusks, were oven-dried for 24 hours at $110^{\circ} \mathrm{C}$ and were ashed at $250^{\circ} \mathrm{C}$ for 24 hours, followed by $450^{\circ} \mathrm{C}$ for 48 hours. The ash rate of samples was 3.6-7.8\% for algae and 1.1-2.3\% for animals. Seawater samples were filtered through 0.45 $\mu \mathrm{m}$ of pore size Millipore filters, then $\mathrm{HNO}_{3}$ was added for string.

For analysis of stable $C s$ in biological samples, ashed samples (300 to $500 \mathrm{mg}$ ) were irradiated in nuclear reactor facility JRR-4 of the Japan Atomic Energy Research Institute for 20 minutes with a flux of about $8 \times 10^{13} \mathrm{n} / \mathrm{cm}^{2} /$ sec. After 28 to 57 days-cooling, gamma-radioactivity of $0.796 \mathrm{MeV}$ was measured for $10,000 \mathrm{sec}$ by a $\mathrm{Ge}(\mathrm{Li})$ detector (ORTEC GEM-10195) and a multichannel analyzer (TRACOR NORTHERN TN-1750), and the concentration of Cs was determined by comparing it with the irradiated standard Cs. For analysis of stable Cs in seawater, samples ( 3 to $10 \mathrm{ml}$ ) were freeze dried, packed into quartz glass tubes, and irradiated in a nuclear reactor facility JRR-2 of the Japan Atomic Energy Research Institute, for 265.5 hours with a flux about $3 \times 10^{13} \mathrm{n} / \mathrm{cm}^{2} / \mathrm{sec}$. After 31 to 60 days-cooling, gamma-radioactivity was measured by the same method as the biological samples.

For analysis of $\mathrm{K}$, ashed samples (300 to $500 \mathrm{mg}$ ) were digested with $\mathrm{HNO}_{3}$ and analyzed by an atomic absorption spectrometer (HITACHI Z-6000). Seawater samples were diluted and acidified by $\mathrm{HNO}_{3}$, and analyzed by the same method.

The errors of stable Cs analysis were $< \pm 7 \%,< \pm 31 \%$, $< \pm 14 \%$ of the values for seawater, algae and marine animal samples, respectively. The errors of $K$ analysis were $< \pm 3 \%,< \pm 8 \%$ of the values for seawater and biological samples, respectively. The sensitivity limits of Cs determination were $0.01 \mu \mathrm{g} / \mathrm{l}$ for seawater and $0.1 \mathrm{ng} / \mathrm{g}$ for biological wet samples. Those of $\mathrm{K}$ determination were $10 \mathrm{mg} / \mathrm{l}$ for seawater and $0.05 \mathrm{mg} / \mathrm{g}$ for biological wet samples.

The accuracy of the values of analysis were assured by the reference standard materials of NIES No. 1 (pepper bush), NIES No. 6 (mussel), NBS SRM 1572 (citrus leaves), and IAEA SL-1 (lake sediment), as shown in Table 1. The

Table 1. Analyzed values of standard reference materials

\begin{tabular}{|c|c|c|c|}
\hline Element & $\begin{array}{l}\text { Reference } \\
\text { material }\end{array}$ & Certified value & Analyzed value \\
\hline \multicolumn{4}{|c|}{ Potassium } \\
\hline & $\begin{array}{l}\text { Pepperbush } \\
\text { (NIES No. 1) }\end{array}$ & $1.51 \pm 0.06$ & $1.47 \pm 0.04$ \\
\hline & $\begin{array}{l}\text { Mussel } \\
\text { (NIES No. 6) }\end{array}$ & $0.54 \pm 0.02$ & $0.54 \pm 0.03$ \\
\hline & $\begin{array}{l}\text { Citrus Leaves } \\
\text { (NBS 1572) }\end{array}$ & 1.82 & 1.81 (Wt. $/ \%)$ \\
\hline \multicolumn{4}{|l|}{ Cesium } \\
\hline & $\begin{array}{l}\text { Pepperbush } \\
\text { (NIES No. 1) }\end{array}$ & $(1.2)^{*}$ & 1.2 \\
\hline & $\begin{array}{r}\text { Citrus Leaves } \\
\text { (NBS 1572) }\end{array}$ & $(0.098)$ & 0.096 \\
\hline & $\begin{array}{l}\text { Lake sediment } \\
\text { (IAEA SL-1) }\end{array}$ & $7.01 \pm 0.88$ & $\begin{array}{l}7.00 \pm 0.70 \\
(\mu \mathrm{g} / \mathrm{g} \text { dry })\end{array}$ \\
\hline
\end{tabular}

\footnotetext{
* Values in parentheses are not certified.
}

results of the analyses showed a satisfactory good agreement with the reference values.

\section{Results}

\section{Cs/K Atom Ratio in Japanese Coastal Waters}

The $\mathrm{Cs} / \mathrm{K}$ atom ratio in seawater are shown in Table 2. Here, we used the atom ratio of $\mathrm{Cs}$ and $\mathrm{K}$ to estimate the number of atoms in samples, instead of the concentration ratio often used in other reports. ${ }^{5-7)}$ The reported Cs concentrations in seawater were 0.15 to $0.5 \mu \mathrm{g} / l^{8,9)}$ The $\mathrm{K}$ concentration in seawater is said to have a near universal value of 399 to $400 \mathrm{mg} / l^{8}{ }^{8} \mathrm{My}$ result showed a values of 0.24 to $0.34 \mu \mathrm{g} / \mathrm{l}$ for $\mathrm{Cs}$ and a value of 370 to $420 \mathrm{mg} / \mathrm{l}$ for $\mathrm{K}$ in Japanese coastal waters. The results indicates that the sampling sites were not affected by river run-off. The $\mathrm{Cs} / \mathrm{K}$ atom ratios were ranging from 1.8 to $2.5 \times 10^{-7}$, which gave the geometric mean value $2.1 \times 10^{-7}$.

\section{$C s$ and $K$ Concentration in Marine Organisms}

The results of the analyses of $\mathrm{Cs}$ and $\mathrm{K}$ in organisms are shown in Table 3. Examination of Table 3 reveals two features: (1) A high concetration of Cs in fish muscle; Cs concentrations in teleosts ranged from 8.8 to $19 \mathrm{ng} / \mathrm{g}$ wet weight, distinctively larger values than those seen in other organisms. (2) High concentrations of $\mathrm{K}$ in Phaeophyta; $\mathrm{K}$ concentrations in phaeophyta ranged from 1.7 to $58 \mathrm{mg} / \mathrm{g}$ wet weight, which were approximately two times higher than those of other algae and marine animals.

Except for Gloiopeltis furcata, the $\mathrm{Cs} / \mathrm{K}$ atom ratios in algal taxa showed an order of magnitude of $10^{-7}$, while $\mathrm{Cs} / \mathrm{K}$ atom ratios in teleosts showed an order of magnitude of $10^{-6}$

\section{Trophic Level Assignments in Food Chains}

Table 4 summarizes the stomach contents of investigat-

Table 2. $\mathrm{Cs} / \mathrm{K}$ atom ratio in Japanese coastal water $(0.45 \mu \mathrm{m}$ filtered)

\begin{tabular}{|c|c|c|c|c|}
\hline \multirow{2}{*}{ Location } & \multirow{2}{*}{ Sampling date } & \multicolumn{2}{|c|}{ Concentration } & \multirow{2}{*}{$\begin{array}{l}\text { Atom ratio } \\
\mathrm{Cs} / \mathrm{K}\left(\times 10^{-7}\right)\end{array}$} \\
\hline & & $\operatorname{Cs} \mu \mathrm{g} / l$ & $\mathrm{~K} \mathrm{mg} / l$ & \\
\hline \multirow[t]{4}{*}{ Oshoro } & 1984.7 .11 & 0.28 & 390 & 2.1 \\
\hline & 1987.7 .15 & $0.3^{* 1}$ & 400 & 2.2 \\
\hline & 1989.7 .12 & 0.30 & 410 & 2.2 \\
\hline & 1990.7 .18 & 0.25 & 370 & 2.0 \\
\hline \multirow[t]{2}{*}{ Rokkasho } & 1989. 8. 3 & 0.33 & 400 & 2.4 \\
\hline & 1990.7 .3 & 0.24 & 370 & 1.9 \\
\hline Sakata & $1984,5.22$ & 0.29 & 420 & 2.0 \\
\hline Sado & 1985. 5. 21 & 0.26 & 400 & 1.9 \\
\hline Katsuura & 1984. 5.16 & 0.25 & 400 & 1.8 \\
\hline \multirow[t]{4}{*}{ Tsuyazaki } & 1985.6 .27 & 0.34 & 390 & 2.5 \\
\hline & 1987.6 .26 & 0.31 & 370 & 2.5 \\
\hline & 1989.7. 5 & $0.3^{* 1}$ & 400 & 2.2 \\
\hline & & $0.29 \pm 0.01^{* 3}$ & $390 \pm 10$ & $2.1 \pm 0.1$ \\
\hline
\end{tabular}

${ }^{*} 0.3 \mu \mathrm{g} / l$ cited from Bowen ${ }^{8}$.

$*_{2} \mathrm{Cs} / \mathrm{K}$ atom ratio $=\frac{\frac{\mu \mathrm{g} / l}{10^{6}} \times \frac{6.02 \times 10^{23}}{133}}{\frac{\mathrm{mg} / l}{10^{3}} \times \frac{6.02 \times 10^{23}}{39.09}}$

* geometric mean and standard error of mean value. 
Table 3. Cs/K atom ratio in marine organisms collected from Japanese coastal waters

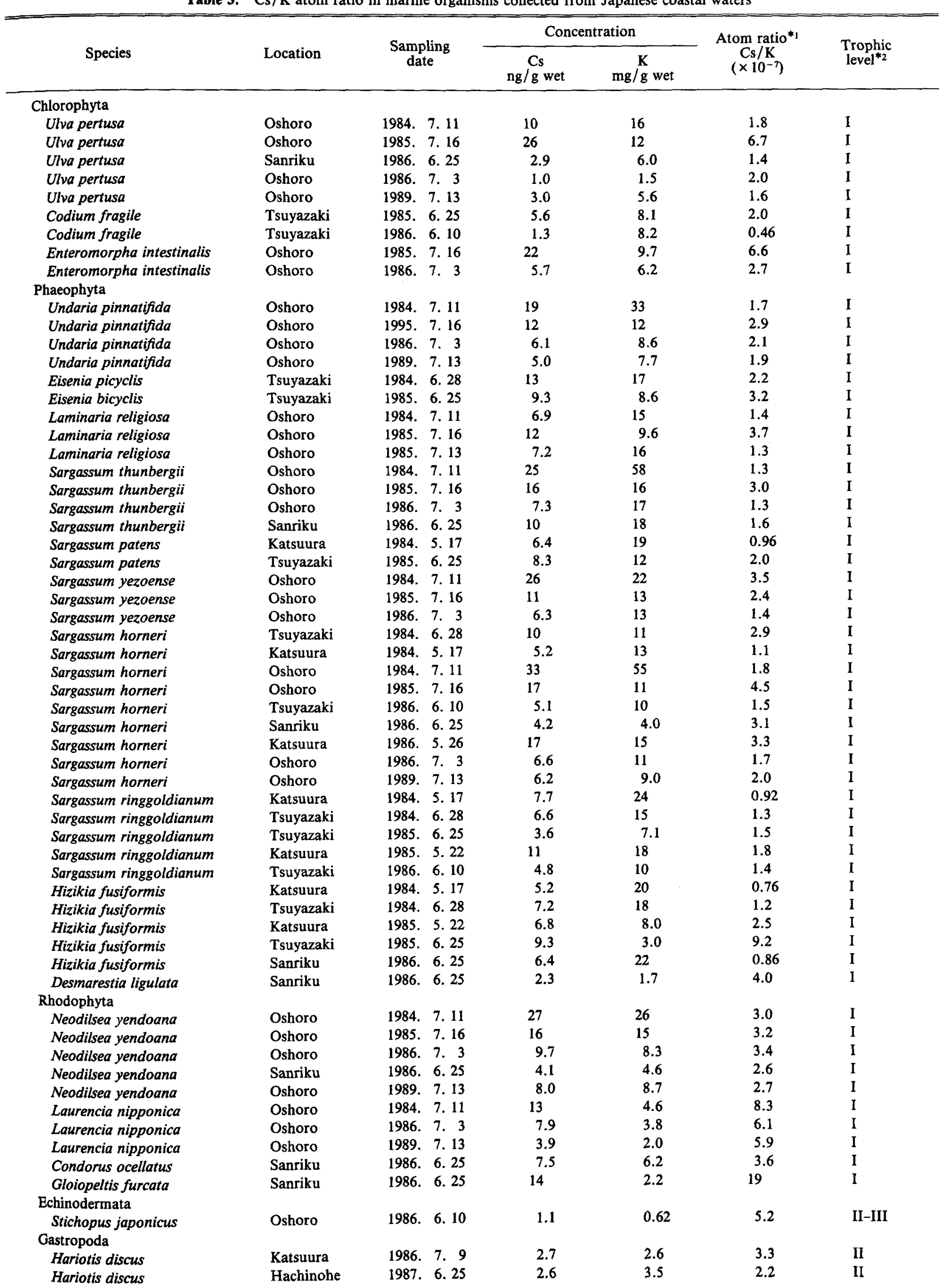


Tabel 3. (continued)

\begin{tabular}{|c|c|c|c|c|c|c|}
\hline \multicolumn{7}{|l|}{ Pelecypoda } \\
\hline Patinopecten yessoensis & Hachinohe & 1986. 6. 3 & 2.1 & 3.7 & 3.6 & II-III \\
\hline Patinopecten yessoensis & Hachinohe & 1987. 8.28 & 6.6 & 4.7 & 4.1 & II-III \\
\hline \multicolumn{7}{|l|}{ Cephalopoda } \\
\hline Paroctopus dolfeini & Hachonohe & 1986. 6. 3 & 3.0 & 3.3 & 2.6 & III-IV \\
\hline Loligo bleekeri & Katsuura & 1986. 5. 27 & 2.3 & 2.0 & 3.4 & II-III \\
\hline Todarodes pacificus & Hachinohe & 1986. 6. 3 & 4.6 & 4.1 & 3.3 & III-IV \\
\hline Todarodes pacificus & Hachinohe & 1987. 7. 9 & 3.2 & 3.7 & 2.6 & III-IV \\
\hline Todarodes pacificus & Hachinohe & 1988. 10.20 & 2.6 & 2.4 & 3.2 & III-IV \\
\hline \multicolumn{7}{|l|}{ Tunicata } \\
\hline Halocynthia roretzi & Hachinohe & 1986. 6. 3 & 5.2 & 1.3 & 12 & II-III \\
\hline Halocynthia roretzi & Hachinohe & 1987. 6. 4 & 3.9 & 5.5 & 2.1 & II-III \\
\hline \multicolumn{7}{|l|}{ Teleost } \\
\hline Parapristipoma trilineatum & Katsuura & 1985. 8.19 & 10 & 4.1 & 7.5 & III-IV \\
\hline Hexagrammos otakii & Katsuura & 1985. 10. 1 & 11 & 2.1 & 16 & III-IV \\
\hline Hexagrammos otakii & Katsuura & 1986. 7. 9 & 13 & 1.5 & 26 & III-IV \\
\hline Hexagrammos otakii & Hachinohe & 1990. 7.19 & 19 & 4.1 & 13 & IV-V \\
\hline Ditrema temmincki & Hachinohe & 1986. 6.3 & 13 & 3.6 & 11 & III-IV \\
\hline Ditrema temmincki & Katsuura & 1986. 7. 9 & 14 & 4.0 & 9.6 & III-IV \\
\hline Ditrema temmincki & Katsuura & 1985. 10. 2 & 11 & 3.6 & 9.2 & III-IV \\
\hline Sebastes inermis & Katsuura & 1985. 8. 26 & 17 & 4.0 & 13 & IV-V \\
\hline Sebastes marmoratus & Katsuura & 1985. 8. 21 & 15 & 4.0 & 11 & IV-V \\
\hline Microstomus ache & Hachinohe & 1986. 6. 3 & 11 & 2.3 & 14 & III-IV \\
\hline Paralichthys olivaceus & Katsuura & 1986. 5. 28 & 15 & 4.1 & 11 & IV-V \\
\hline Paralichthys olivaceus & Hachinohe & 1986. 6. 3 & 11 & 3.6 & 9.0 & IV-V \\
\hline Paralichthys olivaceus & Hachinohe & 1989. 12. 6 & 13 & 3.1 & 12. & IV-V \\
\hline Paralichthys olivaceus & Hachinohe & 1987. 5. 28 & 16 & 3.5 & 13 & IV-V \\
\hline Kareius bicoloratus & Katsuura & 1986. 5. 28 & 9.4 & 4.2 & 6.5 & III-IV \\
\hline Hippoglossoides dubius & Hachinohe & 1987. 6. 25 & 12 & 2.7 & 13 & III-IV \\
\hline Myoxocephalus stelleri & Oshoro & 1990. 7.19 & 12 & 3.5 & 11 & IV-V \\
\hline Sebastes pachycephalus & Katsuura & 1985. 9. 24 & 8.8 & 3.6 & 7.3 & IV-V \\
\hline Sebastes schloegeli & Hachinohe & 1986. 6.3 & 17 & 4.7 & 11 & IV-V \\
\hline Hexgrammos agurammus & Tsuyazaki & 1986. 6. 23 & 13 & 3.5 & 11 & III-IV \\
\hline Sebastes baramenuke & Hachinohe & 1986. 6. 3 & 13 & 2.8 & 14 & IV-V \\
\hline Oncorhynchus keta & Hachinohe & 1987. 10. 25 & 16 & 2.2 & 22 & IV-V \\
\hline
\end{tabular}

$*_{1} \mathrm{Cs} / \mathrm{K}$ atom ratio $=\frac{\frac{\mathrm{ng} / \mathrm{g}}{10^{9}} \times \frac{6.02 \times 10^{23}}{133}}{\frac{\mathrm{mg} / \mathrm{g}}{10^{3}} \times \frac{6.02 \times 10^{23}}{39.09}}$

$*_{2}$ See Table 4. and text.

ed animal samples and the food havits shown in other studies. The trophic levels of each organism were assigned by the trophic level assignment of prey organisms found in stomachs and also determined by food habits reported in other studies. The trophic level categorizations of investigated organisms were basically as follows; trophic level I: producers, which included algae, phytoplankton, and detritus originated from phytoplankton and algae; trophic level II: herbivores, which included herbivorous zooplankton, herbivorous invertebrates, herbivorous fish, detritus originated from zooplankton and bacteria; trophic level III: primary carnivores, which included carnivorous invertebrates and fish; trophic level IV, V: secondary, tertiary carnivores, which were piscipredator fish.

However, organism stomach contents were not so simple to classify. Assignment of trophic level was difficult beacuse most organisms depend on a wide range of prey, including those from different trophic levels. As common prey organisms such as mysids, amphipods, ophiuroids, decapods, and copepods were assigned to the intermediate trophic levels II and III (expressed as II-III in Table 4), most predator organisms were assigned to intermediate trophic levels III and IV (expressed as III-IV). In the same way, the predator organisms that ingested prey organisms of trophic level III and IV were assigned to intermediate levels IV and V (expressed as IV-V). As reports on both of stomach content and food habits were scarce for Patinopecten yessoensis, Sebastes marmoratus, Segastes pachycephalus and Sebastes baramenuke, we assumed their trophic levels were the same as those of organisms of the same taxonomical species. The final trophic level categorization of each organism is shown in Table 3.

In natural environments, trophic levels of the same species were known to vary reflecting dietary changes with predator growth, ${ }^{10}$ the seasonal changes in trophic structures and species composition in ecosystems. ${ }^{11}$ But in this study, a radical change of feeding habits did not occur from May to August. ${ }^{11}$ Thus we could assume that stomach contents of samples reflected the feeding habits of investigated organisms during the previous few months.

\section{Discussion}

$C s$ and $K$ Concentration Factors in Marine Organisms

$\mathrm{K}$ is known as an essential element, while $C s$ is not recognized as an essential element in marine organisms at the 
Table 4. Trophic level assignment by stomach contents and reported food items

\begin{tabular}{|c|c|c|c|c|c|}
\hline Species & Location & $\begin{array}{l}\text { Sampling } \\
\text { date }\end{array}$ & $\begin{array}{l}\text { Stomach contents } \\
\text { (wetr weight perdentage) }\end{array}$ & $\begin{array}{l}\text { Reported } \\
\text { food items }\end{array}$ & $\begin{array}{l}\text { Trophic leve } \\
\text { assignmnt }\end{array}$ \\
\hline Hariotis descus & Katsuura & 1986. 7. 9 & algae Undaric & , Desmarestia, Alaria, Eisenia ${ }^{22)}$ & II \\
\hline Halocynthia roretzi & Hachinohe & 1987. 6.4 & mud, phytoplankton, detritus & & II-III \\
\hline Stichopus japonicus & Oshoro & 1990.7 .13 & mud, detritus & & II-III \\
\hline Loligo bleekeri & Tsuyazaki & 1986. 6.13 & fish larva & & II-III \\
\hline Todarodes pacificus & Hachinohe & 1988.10 .20 & mysids, fish, cephalopods & & III-IV \\
\hline Paroctopus dolfeini & Hachinohe & 1988.10 .20 & & decapods $^{23}$ ) & III-IV \\
\hline Parapristipoma trilineatum & Katsuura & 1985.8 .19 & amphipods & mysids, copepods, bivalves ${ }^{24)}$ & III-IV \\
\hline Ditrema temmincki & Hachinohe & 1986. 6. 3 & decapods & gammarids, amphipods 25 ) & III-IV \\
\hline Ditrema temmincki & Katsuura & 1986. 7. 9 & amphipods & & III-IV \\
\hline Microstomus achne & Hachinohe & 1986. 6.3 & amphipods $(98 \%)$, annelids & & III-IV \\
\hline Kareius bicoloratus & Katsuura & 1986. 5.26 & & olchaeta, Pinnixa, Ammodytes ${ }^{26}$ & III-IV \\
\hline Hippoglossoides dubius & Hachinohe & 1987. 6.25 & Ophiuroids & & III-IV \\
\hline Hexagrammos agurammus & Tsuyazaki & 1986. 6.23 & amphipods, annelids & amphipods, isopods ${ }^{27}$ & III-IV \\
\hline Sebastes inermis & Katsuura & 1985. 8. 26 & amphipods, decapods & amphipods, isopods ${ }^{27}$ & III-IV \\
\hline Hexagrammos otakii & Hachinohe & 1986. 6.13 & fish (50\%), amphipods (40\%), eg & & III-IV \\
\hline Hexagrammos otakii & Katsuura & 1985.7. 9 & amphipods, annelids, decapods & & III-IV \\
\hline Hexagrammos otakii & Hachinohe & 1990.7 .19 & fish $(61 \%)$, decapods $(22 \%)$ & & IV-V \\
\hline Paralichthys olivaceus & Katsuura & 1986. 5. 28 & fish $(90 \%)$, amphipods & Ammodytes, Engraulis ${ }^{26)}$ & IV-V \\
\hline Paralichthys olivaceus & Hachinohe & 1986. 6. 3 & fish $(90 \%)$, cephalopods & & IV-V \\
\hline Myoxocephalus stelleri & Oshoro & 1989. 7.19 & fish $(95 \%)$, cephalopods & & IV-V \\
\hline Sebastes schelegeli & Hachinohe & 1986. 6. 3 & fish, cephalopods & fish, Natantia, Branchyura ${ }^{27}$ & IV-V \\
\hline Oncorhynchus keta & Hachinohe & 1987.10 .25 & fish, amphipods & fish $^{28)}$ & IV-V \\
\hline
\end{tabular}

Trophic levels of prey were estimated as follows; phytoplankton, algae: I, detritus: I, II, ${ }^{29}$ bacteria: II, mysids: II, III, ${ }^{30)}$ amphipods: II, III, ${ }^{31)}$ ophiuroids: II, III, ${ }^{32)}$ decapods: II, III, ${ }^{33-35)}$ copepoda: II, III, ${ }^{36,37)}$ annelids: II, III, ${ }^{29)}$ fish: III, IV, ${ }^{38)}$ shrimp: II, III, ${ }^{39)}$ bivalves: II, III. ${ }^{40)}$

present time. ${ }^{8)}$ Therefore, some difference of behavior of the elements during metabolism in organisms could be expected, which will cause the concentration factors of these two elemets to differ. $\left.{ }^{3}\right)$

The concentration factors of $\mathrm{Cs}$ and $\mathrm{K}$ in organisms of different taxa investigated are shown in Table 5. The data distributions shown log-normal distributions as shown in Figs. 2 and 3. As normalities were assured by taking natural logarithms of the data, statistic comparisons were completed by the analysis of variance tests with a significant level of $\mathrm{p}<0.05$.

The results as shown in Table 5 reveal the differences in the order of concentration factors among different taxa. In the marine animals examined, $\mathrm{K}$ concentration factors were relatively small and showed the same order of magnitude in invertebrates and teleosts, while the Cs concentration factors were significantly larger in teleosts than in invertebrates. This result suggests that $\mathrm{Cs}$ shows different charastaristics than $\mathbf{K}$ in alkali element metabolism of teleosts. $\mathrm{K}$ concentration factors in algae were significantly larger than those in animals, while the $\mathrm{Cs}$ concentration factors in algae were not significantly different from those of teleosts, but larger than those of invertebrates.

Among the algal taxa, The Cs concentration factors of chlorophyta were significantly lower than those of the other two algal taxa, as shown in Fig. 2, while K concentration factors were significantly larger in phaeophyta than those in other algal taxa as shown in Fig. 3. There were two contradictory reports about Cs concentration factors in algae. One was a report by Pentreath ${ }^{12)}$ on algae in the North Sea, which showed that chlorophyta accumulated Cs more than phaeophyta and rhodophyta. The other report was a recent CF review by Gomez et al., ${ }^{13)}$ which in-
Table 5. Cs and $\mathrm{K}$ concentration factors in marine organisms of different taxa

\begin{tabular}{lrccccc}
\hline \hline & \multicolumn{3}{c}{$\begin{array}{c}\text { Concentrtaion } \\
\text { factor of } \mathrm{Cs}^{* 1}\end{array}$} & & \multicolumn{2}{c}{$\begin{array}{c}\text { Concentration } \\
\text { factor of } \mathrm{K}^{* 2}\end{array}$} \\
\cline { 2 - 4 } \cline { 6 - 7 } & $\mathrm{n}$ & mean \pm S.E. ${ }^{* 3}$ & range & & mean \pm S.E. & range \\
\hline Chlorophyta & 9 & $17 \pm 11$ & $3.6-90$ & & $18 \pm 4$ & $3.8-41$ \\
Phaeophyta & 34 & $29 \pm 4$ & $7.9-110$ & & $33 \pm 5$ & $4.3-150$ \\
Rhodophyta & 10 & $33 \pm 7$ & $13-93$ & & $15 \pm 6$ & $5.1-67$ \\
Invertebrates & 12 & $10 \pm 2$ & $3.8-23$ & & $7.0 \pm 1$ & $1.6-14$ \\
Teleosts & 22 & $45 \pm 2$ & $30-66$ & & $8.7 \pm 0.4$ & $3.8-12$ \\
\hline
\end{tabular}

* $_{1}$ Estimated concentration factor by the equation: ( $\mathrm{Cs} \mathrm{ng} / \mathrm{g}$ wet in organism) / (Cs $0.29 \mathrm{ng} / \mathrm{m} /$ in Japanese coastal waters from Table 2).

*2 $_{2}$ Estimated cncentration factor by the equation: $(\mathrm{K} \mathrm{mg} / \mathrm{g}$ wet in organism)/(K $0.39 \mathrm{mg} / \mathrm{m} /$ in Japanese coastal waters from Table 2 ).

${ }^{*}$ Geometric mean and standard error of mean value.

dicated that concentration factors of phaeophyta was the largest, followed by those of rhodophyta and chlorophyta, respectively. My findings of $\mathrm{Cs}$ concentration factors did not agree with either the results shown by Pentreath ${ }^{12)}$ or Gomez et $a l .^{13)}$ The reason for this inconsistency can likely be attributed to the fewer number of data used in those reports.

\section{Cs/K Atom Ratio in Marine Organisms}

$\mathrm{Cs} / \mathrm{K}$ atom ratios in marine organisms are shown in Table 6, and the distributions of data are shown in Fig. 4. The data showed three salient features. (1) In chlorophyta and phaeophyta, Cs/K atom ratios showed no significant difference from those of seawater. This result means no obvious difference is present in uptake behavior of these two 

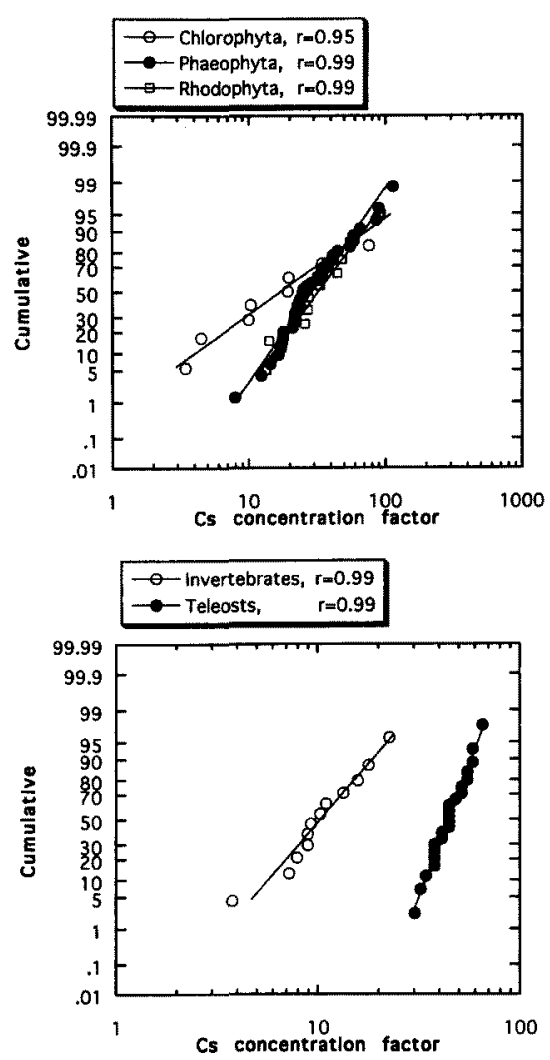

Fig. 2. Cumulatives plots of Cs concentration factors of biological samples.

Regression coefficients between cumulative and Cs concentration factor are shown with legends.

elements between these two algal taxa. In contrast, rhodophyta showed significantly higher $\mathrm{Cs} / \mathrm{K}$ atom ratios than those of seawater. This suggests the presence of relatively large stable Cs metabolic pools in this algal taxon. (2) In teleosts, a significant difference in $\mathrm{Cs} / \mathrm{K}$ atom ratios was detected compared to those of other organisms. Suzuki ${ }^{7}$ reported a mean value of $22 \times 10^{-7}$ for 11 species of Japanese teleosts. Both my data and Suzuki's data indicated that $\mathrm{Cs} / \mathrm{K}$ atom ratios were obviously high in teleosts. This suggests the $\mathrm{Cs}$ discriminated from $\mathrm{K}$ during alkali element metabolism in teleosts. (3) Marine invertebrates showed significantly smaller $\mathrm{Cs} / \mathrm{K}$ atom ratios than those of teleosts. However, reported $\mathrm{Cs} / \mathrm{K}$ ratios in squids had larger values $\left(9.5 \times 10^{-7}{ }^{14)}\right.$ and $\left.5.6 \times 10^{-7}{ }^{6}\right)$ than those in my study. Additionally, some invertebrates were known to show larger ratios of (Cs concentration in tissue)/(Cs concentration in blood) or (Cs concentration in blood) $/(\mathrm{Cs}$ concentration in seawater) than retios of $(\mathrm{K}$ concentration in tissue)/( $\mathrm{K}$ concentration in blood) or ( $\mathrm{K}$ concentration in blood)/( $\mathrm{K}$ concentration in seawater). ${ }^{1,3)}$ Therefore, we can tentatively assume that the discrimination of $\mathrm{Cs}$ from $\mathrm{K}$ also occur in invertebrates. A possible explanation for the discrimination of $\mathrm{Cs}$ from $\mathrm{K}$ in invertebrates is the difference in permeability between these two ions on their body surfaces. Bryan showed, however, that similar blood/seawater concentration ratios of Cs relative to $\mathrm{K}$ in marine decapod crustaceans which have no ability
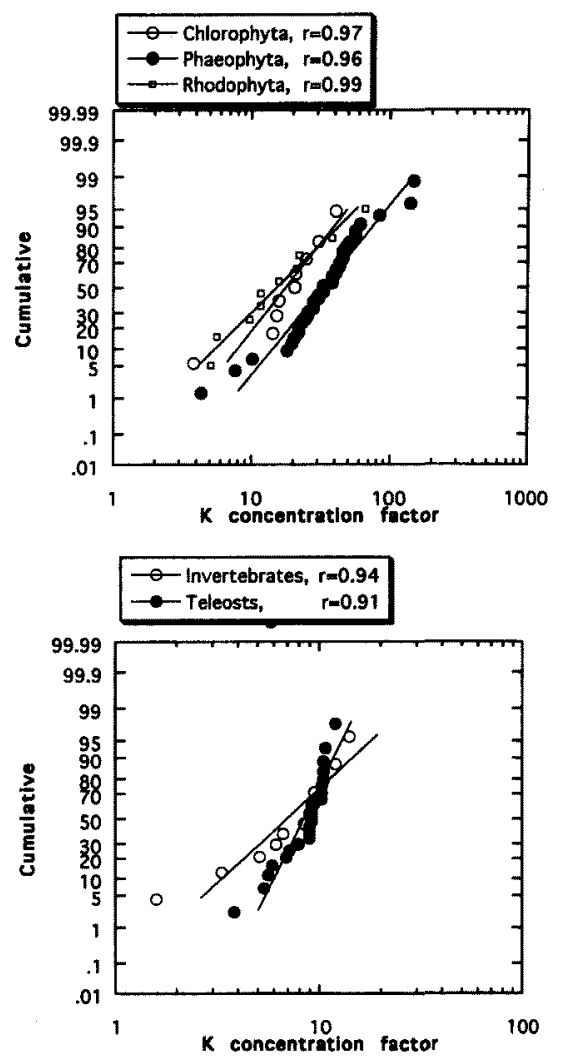

Fig. 3. Cumulatives plots of $\mathrm{K}$ concentration factors in biological sam. ples.

Regression coefficients between cumulative and $\mathbf{K}$ concentration factor are shown with legends.

of osmoregulation. ${ }^{3)}$ Thus, the difference of permeability in passive diffusion would be the least probable. At present, further physiological study is desired.

\section{$C s$, and $K$ Concentration Factors of Organisms and Troph-} ic Levels

The results of concentration factors of $\mathrm{Cs}$ and $\mathrm{K}$ in coastal biota with their assigned trophic levels are summarized in Table 7. The concentration factors of Cs were significantly low in animals of lower trophic levels, such as detoritivores and plankton feeders, while Cs concentration factors were significantly high in animals of higher trophic level, such a carnivores. These results agreed with the findings Osterberg et al. ${ }^{15)}$ However, concentration factors of

Table 6. Cs/K atom ratios in marine organisms of different taxa

\begin{tabular}{lrcc}
\hline & \multicolumn{3}{c}{$\mathrm{Cs} / \mathrm{K}\left(\times 10^{-7}\right)$ atom ratio } \\
\cline { 2 - 4 } & $\mathrm{n}$ & mean \pm S.E. & range \\
\hline Seawater & 12 & $2.1 \pm 0.1$ & $1.8-2.5$ \\
Chlorophyta & 9 & $2.1 \pm 0.8$ & $0.5-6.7$ \\
Phaeophyta & 38 & $1.9 \pm 0.2$ & $0.8-9.2$ \\
Rhodophyta & 10 & $4.6 \pm 1.6$ & $2.6-19$ \\
Invertebrates & 12 & $3.5 \pm 0.8$ & $2.1-12$ \\
Teleosts & 22 & $12 \pm 1$ & $6.5-26$ \\
\hline
\end{tabular}

* Geometric mean and standard error of mean value. 

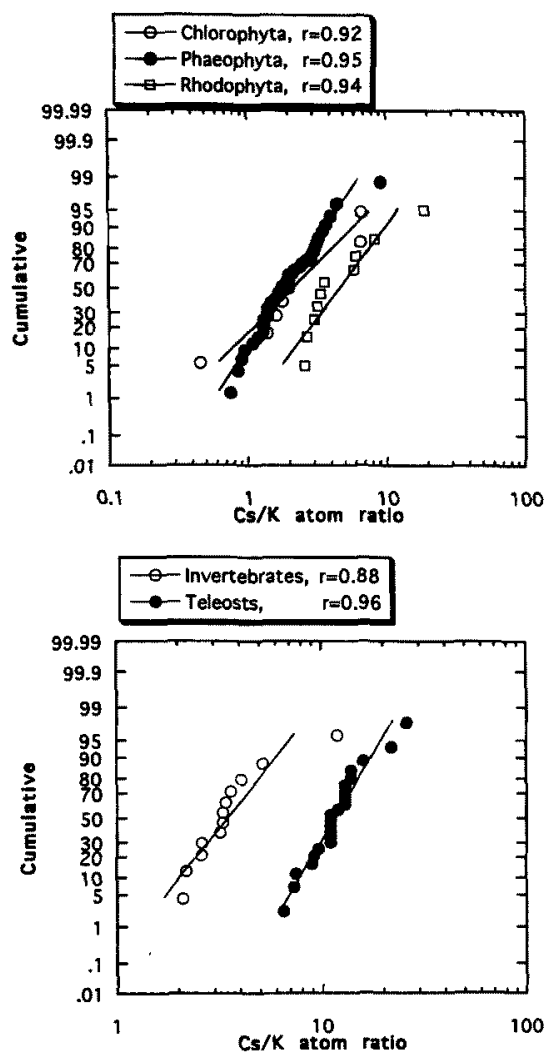

Fig. 4. Cumulatives plots of $\mathrm{Cs} / \mathrm{K}$ atom ratios in biological samples. Regression coefficients between cumulative and $\mathrm{Cs} / \mathrm{K}$ atom ratio are shown with legends.

Cs were not the lowest in producers, such as algae, In fact, the factors slightly decreased from trophic levels I to II; from algae to herbivores. The reason for higher concentration factors of $\mathrm{Cs}$ in the producers is considered to be the same as that for the significantly higher concentration of potassium in phaeophyta.

In freshwater ecosystems, Pendleton and Hanson ${ }^{16}$ reported that radiocesium in organisms was concentrated at a level exceeding that of what the organisms fed upon. In marine ecosystems, Osterberg et $a l .{ }^{15)}$ reported radioactive $\mathrm{Cs}$ was present in tuna and prawns; both are representatives of higher trophic levels, but not detected in organisms of lower trophic levels. These results seem to suggest a presence of radioactive $\mathrm{Cs}$ bioaccumulation along food chain. However, $\mathrm{Cs}$ is conservative as an ionic species in marine environements, ${ }^{17)}$ so that the degree of bioaccumulation is smaller than that observed for $\mathrm{Pu}$, which showed 10-100 times higher concentration factors. ${ }^{18)}$ My results indicated rather large concentration factors of stable $\mathrm{Cs}$ in higher trophic level organisms, while Cs concentration factors were not necessarily the lowest in producers. Thus, my conclusion is that $\mathrm{Cs}$ is less bioaccumulated along the steps of food chain than reported in other studies.

\section{Cs/K Atom Ratio in Organisms of Different Trophic Levels}

Changes in the $\mathrm{Cs} / \mathrm{K}$ atom ratios with trophic levels are summarized in Talbe 8 . The distinctive feature of this table is the significant increase of the $\mathrm{Cs} / \mathrm{K}$ atom ratios along the trophic level steps. The ratio is the lowest in the producers and higherst in the carnivorous predators. The values of $\mathrm{Cs} / \mathrm{K}$ atom ratios in organisms of each trophic level were comparable to the ratios reported by others. ${ }^{5,6,14)}$ The relation of $\mathrm{Cs} / \mathrm{K}$ atom ratios and the trophic level in organisms is shown in Fig. 5, with $95 \%$ confidence limits. The relationship is expressed as an equation as follows: In $\left(\mathrm{Cs} / \mathrm{K}\right.$ atom ratio $\left.\times 10^{-7}\right)=\ln 1.41+0.48 \times$ (trophic level), $r=0.72, p<0.0001$. This equation suggests that the $\mathrm{Cs} / \mathrm{K}$ atom ratio increased by 1.62 times per trophic level elevation in the food chain (a derived increasing ratio). Young et $a l .{ }^{\text {s) }}$ showed the derived increasing ratio of $\mathrm{Cs} / \mathrm{K}$ through food chains in the Salton Sea and the San Pedro Channel, with the values of 1.23 to 1.52 . Mearns et al. ${ }^{\text {9 }}$ also reported the increase of $\mathrm{Cs} / \mathrm{K}$ ratio in pelagic food webs in the Southern California Bight and the western tropical Pacific, where the derived increasing ratio was 2.39.

An increase in the $\mathrm{Cs} / \mathrm{K}$ ratio along in the ascending steps of the food chain was first reported by Pendleton $e t$ $a l .,{ }^{19)}$ where the changes in $\mathrm{Cs} / \mathrm{K}$ ratio between two consecutive trophic levels was expressed as an "increasing ratio $[(\mathrm{Cs} / \mathrm{K}$ ratio in predator $) /(\mathrm{Cs} / \mathrm{K}$ ratio in prey)] Young et $a l .^{5)}$ and Mearns et $a l^{6)}$ presented their hypothesis for this phenomenon, which was that the difference in turnover rates of $C s$ and $K$ caused the accumulation of $C s$ compared with $\mathrm{K}$ in organisms. This phenomenon was biomagnified as one stepped up the food chain. ${ }^{6,19)}$ They mentioned that turnover rates of $\mathrm{Cs}$ and $\mathrm{K}$ were undoubtedly different in several animal metabolisms. For example, in freshwater pike, the biological half-lives of $\mathrm{Cs}$ and $\mathrm{K}$ were 1.1-1.64 and $0.46-0.66$ years, respectively, whose average ratio was $2.4: 1 .^{20)}$ For bluegill, it was $4.5: 1 .^{21)}$ The

Table 7. Cs and $\mathrm{K}$ concentration factors in marine organisms of different trophic levels

\begin{tabular}{|c|c|c|c|c|c|c|}
\hline & \multirow{2}{*}{$\begin{array}{c}\text { Trophic } \\
\text { level } \\
\text { Assignment }\end{array}$} & \multicolumn{3}{|c|}{$\begin{array}{l}\text { Concentration } \\
\text { factor of } \mathrm{Cs}^{* 1}\end{array}$} & \multicolumn{2}{|c|}{$\begin{array}{l}\text { Concentration } \\
\text { factor of } K^{* 2}\end{array}$} \\
\hline & & $\mathbf{n}$ & mean $\pm S . E .{ }^{* 3}$ & range & mean $\pm S . E$. & range \\
\hline Producer & I & 57 & $27 \pm 3$ & $3.4-110$ & $26 \pm 4$ & $3.8-150$ \\
\hline Herbivores & II & 2 & $5.9 \pm 2.8$ & $3.8-9.3$ & $3.3 \pm 2.5$ & $1.6-6.7$ \\
\hline Detritivores, Plankton feeders & II-III & 6 & $11 \pm 2.5$ & $7.2-23$ & $8.8 \pm 1.0$ & $5.1-12$ \\
\hline Primary-Secondary carnivores & III-IV & 14 & $31 \pm 4.8$ & $9.0-66$ & $7.8 \pm 0.8$ & $3: 3-14$ \\
\hline Secondary carnivores & IV-V & 12 & $44 \pm 2.6$ & $30-58$ & $8.7 \pm 0.5$ & $5.6-12$ \\
\hline
\end{tabular}

"1 Estimated concentration factor by the equation: (Cs $\mathrm{ng} / \mathrm{g}$ wet in organism) $/(\mathrm{Cs} 0.29 \mathrm{ng} / \mathrm{m} / \mathrm{in}$ Japanese coastal waters from Table 2 ).

*2 Estimated concentration factor by the equation: $(\mathrm{K} \mathrm{mg} / \mathrm{g}$ wet in organism) $/(\mathrm{K} 0.39 \mathrm{mg} / \mathrm{m} /$ in Japanese coastal waters from Table 2 ).

*3 Geometric mean and standard error of mean value. 
Table 8. Cs $/ \mathrm{K}$ atom ratio in marine organisms of different trophic levels

\begin{tabular}{|c|c|c|c|c|}
\hline & \multirow{2}{*}{$\begin{array}{l}\text { Trophic level } \\
\text { Assignment }\end{array}$} & \multicolumn{3}{|c|}{$\mathrm{Cs} / \mathrm{K}\left(\times 10^{-7}\right)$ atom ratio } \\
\hline & & $\mathbf{n}$ & mean \pm S.E.* & range \\
\hline Seawater & & 12 & $2.1 \pm 0.1$ & $1.8-2.5$ \\
\hline Producer & I & 57 & $2.3 \pm 0.4$ & $0.5-19$ \\
\hline Herbivores & II & 2 & $4.1 \pm 1.0$ & $3.3-5.2$ \\
\hline Detritivores, Plankton feeders & II-III & 6 & $3.1 \pm 0.3$ & $2.2-4.1$ \\
\hline Primary-Secondary carnivores & III-IV & 16 & $8.7 \pm 1.6$ & $2.1-26$ \\
\hline Secondary carnivores & IV $-V$ & 11 & $11 \pm 1$ & $6.5-22$ \\
\hline
\end{tabular}

* Geometric mean and standard error of mean value.

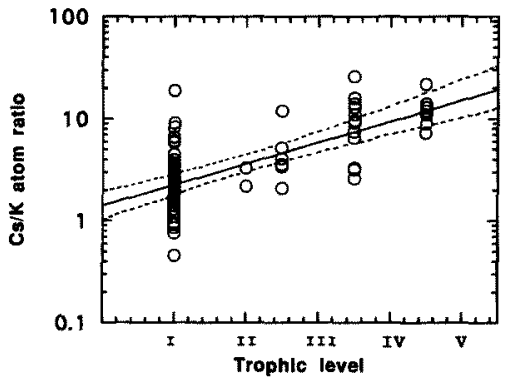

Fig. 5. Regression plot of trophic levels and $\mathrm{Cs} / \mathrm{K}$ atom ratios in collected marine organisms.

The intermediate trophic levels are plotted as the intermediate values. The $95 \%$ confidence bands of geometric mean value are shown in dotted line.

same relation was observed not only in marine crustaceans, ${ }^{1-3,18)}$ but also in humans. In the case of humans, the biological half-lives of $C s$ and $K$ were 20 and 10 days in infants (the ratio was $2: 1$, increasing ratios ranged from 1.3 to 2.5 ), 100 and 25 days in adults (the ratio was $4: 1$, increasing ratios ranged from 2.4 to 5.8$).{ }^{19)}$ Pendleton $e t$ al. ${ }^{19)}$ proved the correlation between the difference in turnover rates of both elements and the magnitude of increasing ratios in humans. Thus, it is probable that the increase of $\mathrm{Cs} / \mathrm{K}$ ratios in marine animals was also attributed to the smaller turnover rates of Cs compared with $\mathrm{K}$ during alkali element metabolism.

As shown in Fig. 5, an increase of the $\mathrm{Cs} / \mathrm{K}$ atom ratio along the food chain was detected. There is a probability that a higher Cs/K ratio in organisms of higher trophic levels may be attributed to the high $\mathrm{Cs} / \mathrm{K}$ atom ratios of teleosts (Table 6). The large $\mathrm{Cs} / \mathrm{K}$ ratio found in teleosts is probably a reffection of both the magnification of the $\mathrm{Cs} /$ $K$ atom ratio by a relative accumulation of $C$ s along the food chain and the specific metabolism of the element in the organisms.

\section{Conclusion}

$\mathrm{Cs} / \mathrm{K}$ atom ratios were studied to clarify the relation of $\mathrm{Cs}$ and $\mathrm{K}$ in the food chains of Japanese coastal waters. The results obtained are: 1) The Cs concentration factors in higher trophic organisms, such as fish, were the largest, while those of lower trophic level organisms in the food chain, such as algae, were not necessarily the lowest. 2) The higher the trophic level, the larger the Cs/K atom ra- tios in the food chain. 3) The derived "increasing ratio" of the $\mathrm{Cs} / \mathrm{K}$ atom ratio was approximately 1.62 in food chains. 4) The probable reasons of the higher $\mathrm{Cs} / \mathrm{K}$ atom ratios in telests were not only the discrimination of $\mathrm{Cs}$ during the alkali element metabolism in animals, but also the Cs accumulation along the food chains.

Acknowledgments I would like to express sincere thanks to Drs. A Nakazono, R. Kado and the staff of Kyushu University, Hokkaido Uni. versity, Kitazato University, Chiba University, Tohoku Regional Fisheries Research Laoboratory, Marine Bio-Environmental Laboratory for their assistance in sample collection. Thanks are also due to Drs. T. Okuda, M. Oota, T. Yoshida, H. Ogawa for advice in the identification of algal species. Additional thanks to Miss N. Sugita for pretreatment of samples. Finally we are grateful to Dr. T. Koyanagi and Dr, M. Shimizu for constructive comments on the manuscript. This work was financially supported by the Central Research Institute of Electric Power Industry.

\section{References}

1) G. W. Bryan: The accumulation of radioactive caesium in crabs. $J$. mar. Biol. Ass. U. K., 41, 551-575 (1961).

2) G. W. Bryan and E. Ward: Potassium metabolism and the accumulation of ${ }^{137} \mathrm{Cs}$ by decapod crustacea. J. mar. Biol. Ass. U. K., 42, 199-241 (1962).

3) G. W. Bryan: Ionic regulation in the squat lobster Galathea squamifera, with special reference to the relationship between potassium metabolism and the accumulation of radioactive caesium. $J$. mar. Biol. Ass. U. K., 45, 97-113 (1965).

4) G. W. Bryan: The accumulation of ${ }^{17} \mathrm{Cs}$ by brackish water invertebrates and its relation to the regulation of potassium and sodium. J. mar. Biol. Ass. U. K., 43, 541-565 (1962).

5) D. R. Young, A. J. Mearns, T. K. Jan, T. C. Heesen, M. D. Moore, R. P. Eganhouse, G. P. Hershelman, and R. W. Gussettn: Trophic structure and pollutant concentrations in marine ecosystems of Southern California. Calif. coop. oceanic Fish. Invest., 21, 197-296 (1980).

6) A. J. Mearns, R. J. Olson, D. R. Young, and H. A. Schafer: Trophic structure and the cesium-potassium ratio in pelagic ecosystem. Calif. coop. oceanic Fish. Invest., 22, 99-110 (1981).

7) Y. Suzuki, R. Nakamura, and T. Ueda: Cesium-137 contamination of marine fishes from the coasts of Japan. J. Radiat. Res., 14, 382391 (1973).

8) H. J. M. Bowen: Environmental chemistry of the elements, Academic Press, London, 1979, pp. 17-34.

9) P. J. Coughtrey and M. C. Thorne: Radionuclide distribution and transport in terrestrial and aquatic ecosystems. A critical review of data, Vol. 1, A. A. Balkema, Rotterdam, 1983, pp. 321-424.

10) S. J. M. Blaber and C. M. Bulman: Diets of fishes of the upper continental slope of eastern Tasmania: content, caloric values, dietary overlap and trophic relationships. Mar. Biol., 95, 345-356 (1987).

11) M. Oomori: On the production ecology of the flatfish, Limando yokohamae-1. Feeding habit and distribution. Nippon Suisan Gakkaishi, 40, 1115-1126 (1974). 
12) R. J. Pentreath: Monitoring of radionuclide. Food Agric. Organ. U. N. Fish. Tech. Dep., 150, 8-27 (1976).

13) L. S. Gomes, M. G. Marietta, and D. W. Jackson: Compilation of selected marine radioecological data for the U. S. Subseabed program: Summaries of available radioecological concentration factors and biological half-lives. Sandia report SAND86-2674 UC-70, 1-90 (1987).

14) T. Izak-Biran and V.P. Guinn: Determination of cesium and potassium in marine species by neutron activation analysis. $J$. radioanalyt. Chem., 55, 61-67 (1980).

15) C. Osterberg, W. G. Pearcy, and F. H. Curl Jr.: Radioactivity and its relationship to ocean food chains. J. mar. Res., 22, 2-12 (1964).

16) R. C. Pendleton, and W. C. Hanson: Absorption of ${ }^{137} \mathrm{Cs}$ by components of an aquatic community. 2nd UN Int. Conf. Peaceful uses of Atomic Energy, 419-422 (1958).

17) P. Shrama, L. R. Gardner, W. S. Moore, and M. S. Bollinger: Sedimentation and bioturbation in salt marsh as revealed by ${ }^{210} \mathrm{pb}$, ${ }^{137} \mathrm{Cs}$, and ${ }^{7}$ Be studies. Limnol. Oceanogr, 32, 313-326 (1987).

18) International Atomic Energy Agency: Sediment Kds and Concentration Facrors for Radionuclides in the Marine Environment, IAEA, Austria, Vienna, 1985, pp. 1-73.

19) R. C. Pendleton, C. W. Mays, R. D. Lloyd, and B. W. Church: A trophic level effect on ${ }^{137} \mathrm{Cs}$ concentration. Health Physics, 11, 1503-1510 (1965).

20) S. Carlsson: A model for the turnover of $\mathrm{Cs}$ and potassium in Pike (Esox lucius). Health Phys., 35, 549-554 (1987).

21) S. E. Kolehmainen and D. J. Nelson: The balances of Cs, stable cesium and the feeding rate of bluegill (Lepomis macrochiras Ref.) and in White Oak Lake, in "Report ORNL-4445 Oak Ridge Nat. Lab.", Oak Ridge Nat. Lab., Oak Ridge, 1969, pp. 1-54.

22) S. Sakai: Ecological studies on the abalone, Hariotis discus HAN. NAI INO-I. Experimental studies on the food habitat. Nippon Suisan Gakkaishi, 28, 766-779 (1962).

23) G. F. Wamer: The biology of crabs, Paul Elek Scientific Book, London, 1977, pp. 1-253.

24) F. Yasuda: The types of food habits of fishes assured by stomach contents examination. Nippon Suisan Gakkaishi, 26, 653-662 (1960).

25) S. Hayase and S. Tanaka: Feeding ecology of three species of embiotocid fishes in the Zostera marina belt of Odawa bay. Nippon Suisan Gakkaishi, 46, 1469-1476 (1980).

26) M. Oomori: A study on the production ecology of demersal fishes in Sendai Bay-II. Interspecific relationships concerning habituated food. Nippon Suisan Gakkaishi, 41, 615-624 (1975).

27) M. Hamanaka and K. Iizuka: Studies in the fish community in the Zostera area-II. Trophic order in a fish group living outside of the Zostera area. Nippon Suisan Gakkaishi, 28, 155-161 (1962).

28) M. Ueno: Food and feeding behavior of Pacific salmon-I. The stratification of food organisms in the stomach. Nippon Suisan Gakkaishi, 34, 315-318 (1968).

29) A. Gremare: Feeding, tube-building and particle-size selection in the terebellid polychaeta Eupolymnia nebulosa. Mar. Biol., 97, 243-252 (1988).

30) L. G. Rudstam, K. Damielson, S. Hansson, and S. Johansson: Diel vertical migration and feeding patterns of Myis mixta (Crustaces, Mysidacea) in the Baltic Sea. Mar. Biol., 101, 43-52 (1989).

31) B. Sainte-Marie: Feeding and swimming of lysianasid amphipods in a shallow cold-water bay. Mar. Biol., 91, 219-229 (1986).

32) N. A. Sloan: Aspects of the feeding biology of asteroids. Oceanogr. mar. Bio. a. Rev., 18, 57-124 (1980).

33) M. H. Deplege: Observations on the feeding behavior of Gaetice depressus (Grapsidae Varuninae) with special reference to suspension feeding. Mar. Biol., 100, 253-259 (1989).

34) D. C. Miller: The feeding mechanism of fiddler crabs, with ecological considerations of feeding adaptations. Zoologica, 46, 89-100 (1961).

35) Y. One: On the ecological distribution of ocpoid crabs in the estuary. Memorials of the Faculty of Science, Kyushu University, Series $E, 4,1-60(1965)$.

36) T. J. Cowles, R. J. Olson, and S. W. Chisholm: Food selection by copepods discrimination on the basis of food quality. Mar. Biol., 100, 41-49 (1988).

37) J. Y. Turner: Zooplankton feeding ecology contents of fecal pellets of the copepods Temora turbinata and $T$. stylifera from continental shelf and slope waters near the mouth of the Mississippi River. Mar. Biol., 82, 73-83 (1984).

38) J. M. Gee: Impacts of epiventhic predation on estuarine intertidal harpacticoid copepoda populations. Mar. Biol., 96, 497-510 (1987).

39) F. Oya: Growth, stomach contents and parasites in a tidepool population of hippolytid shrimp Heptacarpus futilirostris, with reference to reproduction. Mar. Biol, 96, 225-234 (1987).

40) J. M. Amouroux and J. Amouroux: Comparative study of the carbon cycle in Venus verrucosa fed on bacteria and phytoplankton. Mar. Biol., 97, 339-347 (1988). 